\title{
spotlight europe
}

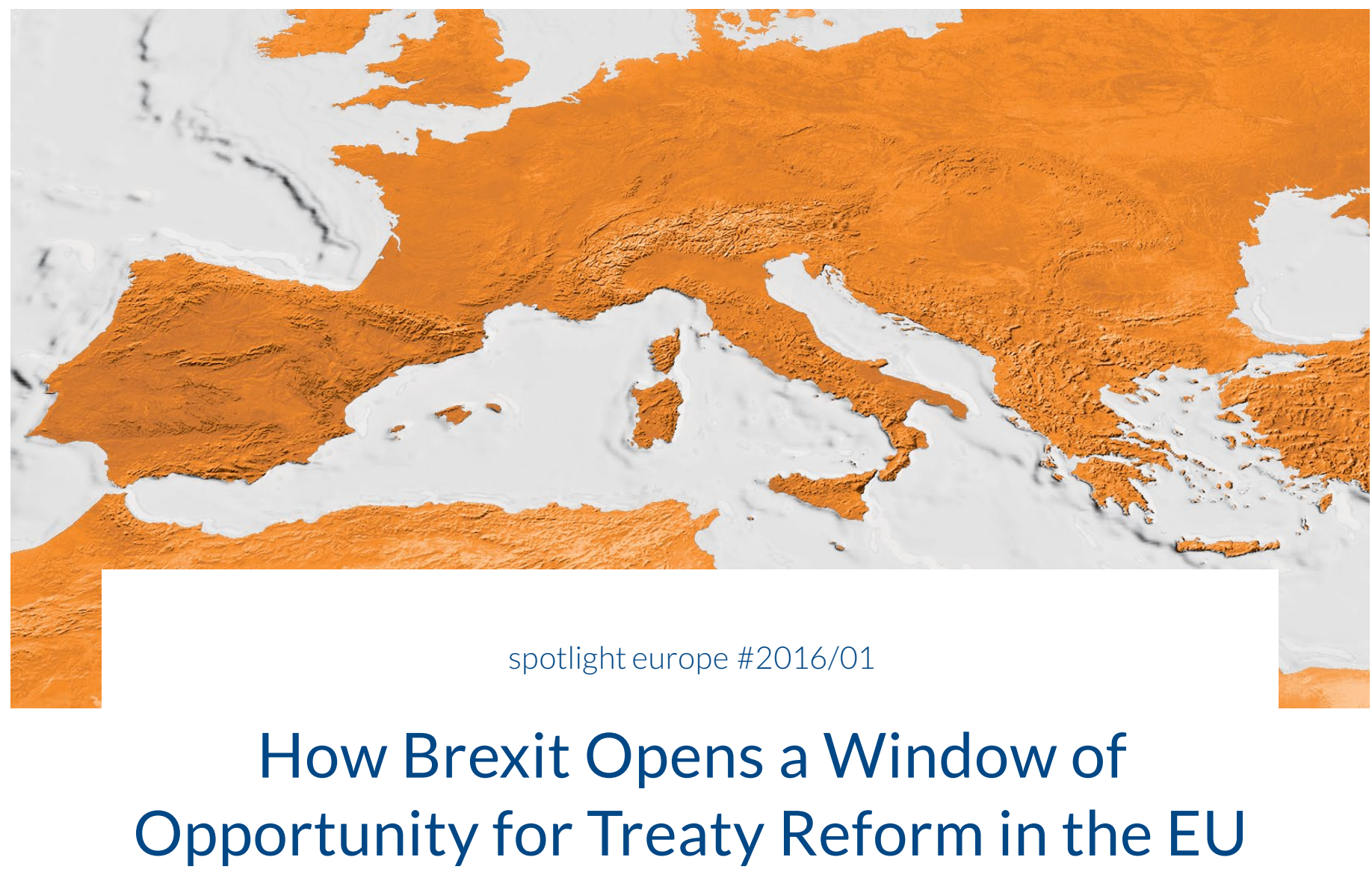

The decision of the UK to leave the EU has important constitutional implications

for the EU. Whether they like it or not, after the UK formally withdraws, the remaining EU member states will need to change the EU treaties and other quasiconstitutional EU laws to account for a new Union at 27. Brexit offers therefore a window of opportunity for a broader constitutional reform of the EU.

by Federico Fabbrini ${ }^{1}$

Dublin City University

\section{Introduction}

The decision of the British people in the June 2016 referendum to leave the European Union (EU) has shocked analysts and policy-makers around the globe. The result of the Brexit referendum has led to major economic and legal uncertainty - revealing the com- plexities of withdrawing from the EU. In the immediate aftermath of the referendum the attention has been focused on the United Kingdom (UK), with urgent questions about the modalities and the timing of the UK's withdrawal from the EU, and discussions about the future potential relations between the UK and the EU. Hence, debates have taken place (and litigation has been started) about who should notify the EU of the UK's decision to leave - whether this can be done by the UK government acting on its own, or whether it requires the assent of Parliament. ${ }^{2}$ Moreover, discussions have emerged about when the

\footnotetext{
1 Federico Fabbrini is Full Professor of EU Law at the School of Law \& Government of Dublin City University. He holds a PhD in Law from the European University Institute.

2 See e.g. Nick Barber et al., "Pulling the Article 50 'Trigger': Parliament's Indispensable Role”, UK Constitutional Law Association Blog, 27 June 2016.
} 
UK is required to officially notify the European Council of its decision to withdraw from the EU. ${ }^{3}$ And several analyses have been produced on what the future relationship between the UK and the EU is going to be - whether the UK should join the European Economic Area (EEA), opt for a Swiss-style solution, or rather go it alone in trading with the EU on the basis of the rules of the World Trade Organization. ${ }^{4}$ Clarity on each of these issues can only be expected to emerge over the coming weeks and months, as the UK works out with the EU the modalities of its secession. ${ }^{5}$

Nevertheless, Brexit does not only impact the UK. In fact, the British decision to leave has important implications for the EU too. The effects of Brexit on the EU are economic and political - but also legal and institutional. This point has so far been largely neglected in the discussions following the referendum's results. This may not be entirely surprising. After all, the very idea that a member state would leave the EU was generally considered to be inconceivable. In fact, according to Giuliano Amato, the main drafter of Article 50 of the Treaty on European Union (TEU) which contains the provision of the EU treaties regulating the withdrawal of a member state from the EU this clause was never actually meant to be used. ${ }^{6}$ Yet, as European policy-makers grapple with the momentous decision by a member state to pull out of the EU, a striking reality seems to emerge: the withdrawal of a country compels the EU and its (remaining) member states to engage in some significant legal and constitutional reforms in order to adapt the EU's legal framework to the new normal of a Union at 27. In short, Brexit produces constitutional consequences, and creates the need for legal and institutional reforms, not only in the UK, but also in the EU.

This paper examines from an EU law perspective some of the most immediate constitutional reforms which the EU and the member states will have to face as a result of Brexit. ${ }^{7}$ As the paper claims, when the UK will complete its withdrawal from the EU pursuant to the procedure set forth in Article $50 \mathrm{TEU}$, the EU and its (remaining) member states will have to amend the EU treaties - specifically changing Article 52 TEU on the territorial scope of EU law. Moreover, the EU institutions and the member states will have to adopt other key legal acts - such as a new decision on the allocation of the seats in the European Parliament, and new rules on the funding of the $\mathrm{EU}$ - which have essentially a constitutional status and in fact require unanimity in the Council, European Parliament's consent, and ratification by the member states in accordance with their respective constitutional requirements. As the paper underlines, therefore, Brexit will call for significant constitutional reforms within the EU, no matter whether the member states and the EU institutions like it or not. As the paper suggests, however, the revisions compelled by the UK's withdrawal offer a window of opportunity to fix several other problems of the current EU institutional set-up. In particular, the need to amend the EU treaties and other quasi-constitutional EU norms provides an opportunity to incorporate into EU law some of the intergovernmental agreements concluded in the aftermath of the Euro-crisis - as argued by the Five Presidents' Report of June $2015^{8}$ - as well as to push forward other reforms consensually regarded as indispensable to put Economic and Monetary Union (EMU) on a more solid grounds. ${ }^{9}$

This paper is structured as follows. Section 2 examines the amendment to the EU treaties necessitated by Brexit. Section 3 outlines the revisions to other sources of EU law of a quasi-constitutional nature which will be inevitably triggered by the withdrawal of the UK. As it will be pointed out, the changes to acts such as the decision on the allocation of seats in the European Parliament or the rules on the financing of the EU are - in terms of complexity - almost akin to an amendment to the EU treaties. As Section 4

3 See e.g. Andrew Duff, "Everything you need to know about Article 50 (but were afraid to ask)", Verfassungsblog, 4 July 2016.

4 See e.g. Jean-Claude Piris, "Which options would be available to the United Kingdom in case of a Withdrawal from the EU?”, CSF-SSSUP Working Paper No 1/2015 and Henrik Enderlein, "What Should Happen? What is Likely to Happen? Notes on Brexit", Jacques Delors Institut - Berlin Policy Paper, 30 June 2016.

5 See also Patrick Birkinshaw and Andrea Biondi (eds), Britain Alone (Wolters Kluwer 2016) and Brexit, Special Supplement (2016) 17 German Law Journal 1.

6 See Christopher Hooton and Jon Stone, “Brexit: Article 50 was never actually meant to be used, says its author”, The Independent, 26 July 2016.

7 See Case 294/83 Les Verts [1986] ECR 1339 (ECJ defining the EU treaties as the EU “constitutional charter”).

8 See President of the European Commission, in collaboration with the Presidents of the European Council, the Eurogroup, the European Central Bank and the European Parliament, report “Completing Europe’s Economic and Monetary Union”, 22 June 2015.

9 See President of the European Central Bank, introductory statement before the Economic and Monetary Affairs Committee of the European Parliament, 15 June 2015 . 
conclusively suggests, therefore, Brexit offers the window of opportunity to pursue other needed reforms of EU primary law.

\section{Amendments to the EU treaties}

The most glaring treaty amendment which will have to be made as a result of the withdrawal of the UK from the EU regards Article 52 TEU. This provision lists the EU member states, and currently reads as follows:

1. The Treaties shall apply to the Kingdom of Belgium, the Republic of Bulgaria, the Czech Republic, the Kingdom of Denmark, the Federal Republic of Germany, the Republic of Estonia, Ireland, the Hellenic Republic, the Kingdom of Spain, the French Republic, the Republic of Croatia, the Italian Republic, the Republic of Cyprus, the Republic of Latvia, the Republic of Lithuania, the Grand Duchy of Luxembourg, the Republic of Hungary, the Republic of Malta, the Kingdom of the Netherlands, the Republic of Austria, the Republic of Poland, the Portuguese Republic, Romania, the Republic of Slovenia, the Slovak Republic, the Republic of Finland, the Kingdom of Sweden and the United Kingdom of Great Britain and Northern Ireland.

2. The territorial scope of the Treaties is specified in Article 355 of the Treaty on the Functioning of the European Union [TFEU].

Article 52 TEU lists the member states of the EU, and has been updated over time to account for the enlargement of the EU. The last amendment to this provision was introduced in 2013, when Croatia joined the EU as its 28th member state. On that occasion, Article 13 of the Act concerning the conditions of accession of the Republic of Croatia, which is annexed to the Treaty between the $27 \mathrm{EU}$ member states and Croatia, modified Article 52 TEU so as to include Croatia in the list of EU member states..$^{10}$ The Treaty of accession of Croatia, like any other previous accession treaty, had to be ratified by the applicant country as well as by all the other EU member states, in accordance with their respective constitutional requirements.

After the UK withdraws from the EU, Article 52 TEU will have to be modified, and the only way to do so is through a treaty revision procedure. In fact, an important point needs to be underlined. Article 49 TEU (which regulates enlargement) explicitly authorizes "adjustments to the Treaties on which the Union is founded" to be made in the accession agreement between the member states and the applicant country. In other words, formal modifications of the EU treaties which result from the accession of a new member state can be dealt with in the accession treaty and accompanying documents - without the need for a revision of the EU treaties according to the rules of Article 48 TEU. On the contrary, Article 50 TEU (which regulates withdrawal) does not mention a specular rule, and merely states that the EU shall "conclude an agreement with [the withdrawing] State, setting out the arrangement for its withdrawal, taking into account of the framework for its future relationship with the Union". Since the withdrawal pact is negotiated by the EU like any other normal international agreement pursuant to the rules of Article 218(3) TFEU - and is thus a legal act which in hierarchical terms is inferior to the EU treaties ${ }^{11}$ - this implies that in order to modify Article 52 TEU and remove the name of the UK from the list of EU member states resort should be made to the normal amendment procedure of Article 48 TEU. An international agreement concluded by the EU, in fact, cannot modify EU primary law. ${ }^{12}$ In other words, whereas in the case of enlargement the accession agreement suffices to introduce formal amendments to the EU treaties (such as a change to Article 52 TEU), in the case of withdrawal the secession agreement cannot do: Here formal adjustments to the EU treaties have to be undertaken through the general revision procedure disciplined in Article 48 TEU.

As is well-known, Article 48 TEU outlines two mechanisms that can be used to amend the EU treaties: a simplified revision procedure, and an ordinary revision procedure. However, according to Article 48(6) TEU the simplified revision procedure can be used only in order to "revise all or part of the provisions of Part Three of the Treaty on the Functioning of the EU" and at the condition that the amendment "shall not increase the competences conferred on the Union in the Treaties". In order to modify Article 52 TEU, therefore, resort has to be made to the ordinary

\footnotetext{
10 See Art 13 Act concerning the conditions of accession of the Republic of Croatia and the adjustments to the Treaty on European Union and the Treaty on the Functioning of the European Union, OJ 2012 L 112/25.

11 See Art 218(11) TFEU.

12 See Paul Craig, The Treaty of Lisbon: Law, Politics and Treaty Reform (Oxford, Oxford University Press 2010 ) 401.
} 
revision procedure. This procedure requires the European Council to "convene a Convention composed of representatives of the national Parliaments, of the Heads of State or Government of the Member States, of the European Parliament and of the Commission" and charged to "adopt by consensus a recommendation [to amend the treaties] to a conference of representatives of the governments of the Member States." Pursuant to Article 48(3) TEU the European Council may decide by a simple majority "not to convene a Convention should this not be justified by the extent of the proposed amendments" - but it must obtain the consent of the European Parliament to do so: hence the European Parliament can insist on calling a Convention to examine proposals for revisions to the EU treaties. ${ }^{13}$ Finally, a conference of representatives of the member states has to determine "by common accord" the amendments to the treaties which "shall enter into force after being ratified by all the Member States in accordance with their respective constitutional requirements."

In sum, when the UK withdraws from the EU, the other member states will have to amend the EU treaties - at the minimum to modify Article 52 TEU. As explained above, the withdrawal agreement cannot be used to amend Article 52 TEU, since an international treaty concluded by the EU under Article 218 TFEU cannot bring about a modification to EU primary law. Moreover, the simplified treaty amendment procedure cannot be used to change Article 52 TEU, which means that the ordinary treaty amendment procedure is required in this context. It is quite possible that the remaining 27 member states in the European Council will quickly settle to modify Article 52 TEU and decide that a Convention is not needed for such a formal amendment. However, as mentioned, Article 48 TEU gives to the European Parliament the right to veto the European Council's position and to insist on convening a Convention. Considering that the European Parliament has called for the establishment of a Convention to fix the EU treaties on multiple occasions, ${ }^{14}$ it cannot be excluded that it will exploit the opportunity created by Brexit to force the European Council to eventually set in motion a broader project of revisions and updates to the EU constitutional documents.

\section{Amendments to other EU legal acts of a quasiconstitutional nature}

Besides the amendment to the EU treaties discussed above - which is macroscopic, but admittedly formal - the (remaining) member states of the EU will also have to revise other EU legal acts which are instead of high substantive and political salience. Following the UK withdrawal from the EU, in particular, the two most important EU legal measures which will need to be revised by the EU institutions and its member states are the decision on the allocation of seats in the European Parliament, and the rules on the financing of the EU. Both these legal acts are formally not treaty amendments, since there is no need to use the procedure of Article $48 \mathrm{TEU}$ to change them. And yet, in substance, these acts have a quasi-constitutional status, since they deal with crucial aspects of the functioning of the EU such as the organization of the European Parliament, and the funding of the EU. In fact, the approval of these acts is subject to special legislative procedures which are akin - for all practical purposes - to a treaty revision: Modifying the decision on the composition of the European Parliament and the decision on the own resources of the EU requires member states' unanimity, and European Parliament involvement, as well as ratification by each member state according to its respective constitutional requirements. The necessity to readopt these crucial EU legal acts to adapt the EU to the departure of the UK will thus compel the member states to engage in the broad and complex bargaining process proper of major constitutional reforms.

\section{The decision establishing the composition of the European Parliament}

When the UK withdraws from the EU, the composition of the European Parliament will have to be modified to account for the secession of one of its (most populous) member states. Whereas the EU treaties provisions dealing with the European Council, the Council and the European Commission can be applied without much ado to a Union at 27, institutional engineering is needed to adapt the European Parliament to the new reality. According to Article 14(2) TEU, in fact, the European Parliament shall be composed of

13 See Jean-Claude Piris, The Lisbon Treaty: A Legal and Political Analysis (Cambridge, Cambridge University Press 2010) 104.

14 See e.g. European Parliament Resolution of 2 February 2012 on the European Council meeting of 30 January 2012, P7_TA(2012)o023 para 9; European Parliament Resolution of 20 November 2012 towards a Genuine EMU, P7_TA(2012)0430 para 6; European Parliament Resolution of 12 December 2013 on the constitutional problems of multi-tier governance in the European Union, P7_TA(2013)0598 paras 67-69. 
750 members, plus the President - hence, for a total of 751 MEPs, to be elected in the various member states according to the principle of degressive proportionality "with a minimum threshold of six members per Member State. No Member State shall be allocated more than ninety-six seats."

As clarified in Article 14(2) TEU too, the specific allocation of European Parliament's seats in the various member states is determined in a European Council decision, "adopted by unanimity, on the initiative of the European Parliament and with its consent." Currently, the composition of the European Parliament is set in a European Council decision adopted in June 2013. ${ }^{15}$ This decision - the first passed since the entry into force of the Lisbon Treaty - determined the apportionment of seats in the 8th European Parliament elections in June 2014 and was the result of a long wrangling among the member states. ${ }^{16}$ In fact, the difficulties to find an acceptable compromise between member states and among EU institutions on the allocation of European Parliament seats emerged prominently in the negotiations leading to the Lisbon Treaty and are reflected in the fact that Declarations No. 4 and No. 5, annexed to the EU treaties, concern specifically this issue. Declaration No. 4, in particular, indicates that "the additional seats in the European Parliament" (i.e. the 751st seat) will be attributed to Italy, and Declaration No. 5 states that the European Council "will give its political agreement on the revised draft Decision on the composition of the European Parliament for the legislative period 2009-2014, based on the proposal from the European Parliament." These declarations - which technically are not binding, and do not have the same legal values as the EU treaties - testify however to concerns that member states and EU institutions have on such a delicate issue.

Following the departure of the UK, the member states in the European Council and the European Parliament will have to agree on a new decision on the allocation of seats in the European Parliament. In fact, the June 2013 European Council decisions already anticipated that a new formula for the allocation of seats had to be agreed upon in view of the 9th European Parliament elections in 2019, ${ }^{17}$ and the European Parliament is expected to come up with a proposal shortly. Yet, it is clear that the withdrawal of the UK creates space for major new demands by several countries, and potentially for a heavy reshuffling of seats. In fact, the currently binding European Council decision assigns to the UK 73 seats in the European Parliament - the third largest delegation (after Germany and France, and on a par with Italy)..$^{18}$ The new apportionment decision will have to be proposed by the Parliament, approved unanimously by the European Council, sanctioned by the European Parliament; and then de facto it will have to be ratified domestically by each of the member states, since national legislation will need to be put in place to regulate the specific modalities for electing the number of MEPs assigned to each member state by the EU decision. It is clear therefore that much will be at stake during the negotiations. After all, comparative studies reveal that choices on the allocation of seats in compound or federal systems are often taken within the framework of broader constitutional bargains, when units which may be losing in terms of corporate representation can be compensated with other payoffs. ${ }^{19}$

In sum, the need to adopt a new decision on the composition of the European Parliament after Brexit seems to create once more a window of opportunity for significant updates and revisions to the EU institutional set-up. Amending the decision on the allocation of seats within the European Parliament is - in terms of complexity - almost tantamount to a treaty revision. It cannot be excluded therefore that some institutions, or some member states, may exploit this opportunity to call for a more fully-fledged change to the EU institutional architecture, or at least to some other specific amendments to EU primary law. As a result, the adoption of a new decision on apportionment of seats in the European Parliament may trigger pressures for a broader package-deal with more far-reaching constitutional consequence.

15 European Council Decision of 28 June 2013 establishing the composition of the European Parliament, 2013/312/EU, OJ 2013 L 181/57.

16 See further Federico Fabbrini, "Representation in the European Parliament: of False Problems and Real Challenges" (2015) 75 Zeitschrift für ausländisches öffentliches Recht und Völkerrecht 823.

17 See Art 5, European Council Decision 2013/312/EU.

18 See Art 3, European Council Decision 2013/312/EU.

19 See Jonathan Rodden, "Strength in Numbers? Representation and Redistribution in the European Union" (2002) European Union Politics 151. 


\section{Financial provisions}

In addition to the new rules on the allocation of seats for the European Parliament, another legal area where major changes will be necessitated in the EU by Brexit concerns the rules on the financing of the EU: after the UK withdraws from the EU, the system of revenues and expenditures of the EU will need to be largely reformed. The provisions of the EU treaties regulating the financing of the EU set up a highly technical and complex system. In a nutshell, however, the system can be described as follows. First, under Article 312 TFEU, the Council, acting unanimously and with the consent of the European Parliament shall adopt a regulation laying down the multiannual financial framework (MFF) of the EU: this regulation, usually adopted for a 7-year time-span, "shall ensure that Union expenditure develops in an orderly manner". Second, under Article 311 TFEU, the Council, acting unanimously and after consulting the European Parliament shall adopt a decision laying down the system of own resources of the Union: this decision - which "shall not enter into force until it is approved by the Member States in accordance with their respective constitutional requirements" - defines the revenue side of the EU financing, and thus complements the MFF regulation which instead sets the expenditure side. Third, based on the funding prospect set in the own resources decision and in light of the expenditure plan sketched in the MFF regulation, the European Parliament and the Council adopt every year the annual budget of the $\mathrm{EU}$, according to the detailed procedural rules enshrined in Article 314 TFEU.

The current rules on the financing of the EU were set in a package of legal measures adopted after the entry into force of the Lisbon Treaty. In particular, on the revenue side, the own resources of the EU are set in a Council decision adopted in May 2014. ${ }^{20}$ On the expenditure side, instead, rules are condensed in a Council regulation adopted in December 2013, which sets the MFF for 2014-2020. ${ }^{21}$ Both these legal measures were the result of highly complex political negotiations. A proposal for a new own resources decision was tabled by the Commission in 2011, ,2 $^{2}$ and it took 3 years to approve it in the Council: in fact, the own resources decision is still subject to parliamentary ratification in several member states (but will apply retroactively as from 1 January 2014, when national ratification will be completed). ${ }^{23}$ At the same time, negotiations for the MFF 2014-2020 broke down on several occasions, and the intervention of the European Council (in place of the Council) was necessary in order to find a compromise among the member states. ${ }^{24}$

As is well-known, the difficulties in negotiating the own resources decision and the MFF regulation are a result of the way in which the EU is currently funded. ${ }^{25}$ Despite the letter and the spirit of the EU treaties, EU resources are today mostly transferred to Brussels from member states' coffers: EU countries therefore consider the contributions they make to the EU budget as their money, and aggressively measure the difference between their contributions to, and their receipts from, the EU budget. As a result of this state of affairs, the decision-making process about the EU budget has been captured by endless negotiation among the member states about the precise costs and benefits that each country would incur. Because no member state its willing to transfer its money to the EU budget for the benefit of other member states, the discussion about the EU funding have become increasingly costly and decreasingly effective - every member state having a veto power on how much resources the EU should raise and how it should spend.

Given this situation, it is to be expected that after the withdrawal of the UK the negotiations of the new EU financial framework will be highly contentious. Although the UK enjoys a famous rebate (obtained in 1984, and preserved ever since) which allows it to pay less than it should, it still remains one of the major contributors to the EU budget - the 4th total net payer into the EU coffers (after Germany, France and Italy), according to the latest figures of the European Commission (for 2014). ${ }^{26}$ Hence, when the UK will

20 Council Decision of 26 May 2014 on the system of own resources of the European Union, 2014/335/EU, Euratom, OJ 2014 L 168/105.

21 Council Regulation (EU, Euratom) No 1311/2013 of 2 December 2013 laying down the multiannual financial framework for the years $2014-2020$, OJ 2013 L 347/884.

22 See Commission proposal for a Council Decision on the system of own resources of the European Union, 29 June 2011, COM(2011)510 final.

23 See Art 11 Council Decision 2014/335/EU, Euratom.

24 See European Council meeting, 22-23 November 2012 (failing to reach agreement on MFF).

25 See further Federico Fabbrini, "Taxing and Spending in the Eurozone" (2014) 39 European Law Review 155.

26 See European Commission, “EU Expenditure and Revenue 2014-2020”, interactive chart available at http://ec.europa.eu/budget/figures/interactive/index_en.cfm. 
pull out of the EU - and unless the UK joins the EEA, a solution which would compel it to contribute to the EU budget as a condition to keeping access to the internal market ${ }^{27}$ - the question will arise of how to handle the loss of UK contributions to the EU budget. In principle, the EU could reduce expenditures in proportion to the UK quota - but it seems unlikely that member states which are net beneficiaries of EU spending would endorse such an outcome. Alternatively, the member states (a.k.a. essentially the countries which are net contributors to the EU budget) could increase their contributions to wind-up the shortfall resulting from Brexit - but again it seems unlikely that countries which are already paying into the EU budget more than what they get in return would endorse this option. In this context, therefore, it cannot be excluded that Brexit will create a window of opportunity for a more significant constitutional rethinking of the EU financing system. ${ }^{28}$

From this point of view, Brexit would feed into an ongoing discussion, tipping the balance in favor of some kind of legal reform. While the European Parliament has been pressing for the creation of a EU fiscal capacity through real EU taxes ${ }^{29}$ - a development which would be legally possible under Article 311 TFEU - a High Level Group on Own Resources chaired by former Commissioner and Italian Prime Minister Mario Monti is currently drafting a report with proposals to reform the EU system of own resources. ${ }^{30}$ Although until now member states' governments have been lukewarm at these initiatives, in the aftermath of Brexit the idea of endowing the EU with adequate taxing and spending powers - independent from member states' financial transfers - may acquire a new attractiveness as a way to provide adequate funding to the EU.

In sum, the need to adopt new legal rules for EU revenues and expenditures for the post-2020 financial framework attains a new meaning as a consequence of the British decision to secede from the EU. Given the complexities already characterizing the negotiations of the EU financing system, it is to be expected that the withdrawal of one of the (richest) member states will heat up further the tone of the future negotiations, between member states, and among EU institutions. Since the adoption of the MFF regulation, and even more so of the own resources decision, are practically tantamount to a treaty revision - as reflected in the need of state ratifications according to national constitutional requirements - major challenges are to be expected. Ironically, however, as the UK has traditionally been the strongest opponent to any initiative in favor of expanding the EU taxing powers, or of re-designing the EU spending system, its withdrawal from the EU may increase the chances that the (remaining) member states will agree on a reform of the EU financing system.

\section{Conclusion}

This paper explained that Brexit produces constitutional implications not only for the UK but also for the EU. While in the immediate aftermath of the June 2016 British referendum scholars' and policy-makers' attention has focused on the UK-side of the story, this paper has sought to highlight how the UK withdrawal from the EU will force the EU and its (remaining) 27 member states to engage in significant legal and institutional reforms. Whether they like it or not, the EU and its member states will need to amend the EU treaties, and to revise other EU quasi-constitutional acts, in order to adapt the EU to a new reality of a Union at 27.

In particular, as this paper has pointed out, changes have to be made - at a minimum - to Article 52 TEU, as well as to the decision on the composition of the European Parliament and the rules on the financing of the EU. While the amendment to Article 52 TEU is purely formal, it can only be accomplished through the treaty revision procedure enshrined in Article 48 TEU. At the same time, while the amendments to the decision on the composition of the European Parliament and to the decision on the own resources (together with the MFF) do not formally amount to treaty change, they require special legislative procedures which make them akin to a treaty revision process.

27 See Art 2 Protocol 38B on the EEA Financial Mechanism (2009-2014) to the EEA Agreement, OJ 2010 L 291/4.

28 See Edoardo Traversa and Alexander Maitrot de la Motte, “Le fédéralisme économique et la fiscalité dans l'Union européenne”, in Stéphane De la Rosa et al. (eds), L’Union européene et le fédéralisme économique (Brussels, Bruylant 2015) 343.

29 See e.g. European Parliament Resolution of 20 November 2012 towards a genuine EMU, P7_TA(2012)0430, para 11; European Parliament Resolution of 23 May 2013 on future legislative proposals on EMU, P7_TA(2013)0222, para 22; European Parliament Resolution of 24 June 2015 on the review of economic governance framework: stocktaking and challenges, P8_TA(2015)0238, para 57(c).

30 See High Level Group on own resources, First Assessment Report, 17 December 2014. 
In this context, this paper suggested that Brexit opens new windows of opportunity for wider constitutional changes in the EU. Resort to Article 48 TEU (to change Article 52 TEU) could be exploited by the European Parliament to push further with other revisions to EU primary law, as it has repeatedly advocated, especially in the field of EMU. Moreover, since the UK is one of the most populous and richest member states of the EU, its withdrawal from the EU will significantly change the stakes of the renegotiation of the decision on the composition of the European Parliament and the rules on EU financing: while these acts were already scheduled to be renewed before 2019 (for the new European Parliament elections) and 2020 (for the new MFF), it seems clear that without the UK the other member states and the EU institutions will need to engage in a much more significant grand bargain, both to re-apportion seats and to re-think the revenues and expenditures of the EU for a post-Brexit era.

Moreover, if one takes into account that the member states which have signed the Treaty on the stability, coordination and governance of EMU (mostly known as the Fiscal Compact) and the Treaty on the transfer and mutualization of contributions to the Single Resolution Fund have committed to bring back the content of these intergovernmental agreements within the framework of EU law by 2018, and 2026 respectively, ${ }^{31}$ it appears that Brexit reinforces the call for changes to the EU constitutional architecture which have been articulated in the context of the Euro-crisis. ${ }^{32}$ Since the domestication within the EU legal order of these interstate compacts (as well as potentially of the Treaty establishing a European Stability Mechanism) requires several revisions to the EU treaties, Brexit offers an excellent opportunity to accomplish what the Five Presidents' Report, and other high-level policy documents, have recommended. ${ }^{33}$

In conclusion, the withdrawal of the UK from the EU will trigger a process of legal and institutional tinkering in the EU, which - if led by political vision railing social support - could be exploited to improve the constitutional architecture of the EU.

31 See Art 16 Treaty on the Stability Coordination and Governance of the EMU and Art 16 Agreement on the Transfer and Mutualization of Contributions to the Single Resolution Fund.

32 See further Federico Fabbrini, Economic Governance in Europe (Oxford, Oxford University Press 2016) 283.

33 See Henrik Enderlein, Enrico Letta, Jörg Asmussen, Laurence Boone, Aart De Geus, Pascal Lamy, Philippe Maystadt, Maria João Rodrigues, Gertrude Tumpel-Gugerell, António Vitorino, Repair and Prepare: Growth and the Euro after Brexit, Gütersloh, Berlin, Paris: Bertelsmann Stiftung, Jacques Delors Institut - Berlin, and Jacques Delors Institute in Paris, forthcoming 2016.

\section{Imprint}

(C) 2016 Bertelsmann Stiftung

Bertelsmann Stiftung

Carl-Bertelsmann-Straße 256

33311 Gütersloh | Germany

$\rightarrow$ www.bertelsmann-stiftung.de

Responsible:

Dr. Katharina Gnath

katharina.gnath@bertelsmann-stiftung.de

Tel. +495241 81-81183

$\rightarrow$ www.bertelsmann-stiftung.de/europe
Repair and Prepare |||| Strengthen the euro

This publication is part of Repair and Prepare: Strenghten the euro, a larger research project of the Bertelsmann Stiftung and the Jacques Delors Institut - Berlin.

$\rightarrow$ www.strengthentheeuro.eu

All spotlight europe editions can be downloaded at:

$\longrightarrow$ www.bertelsmann-stiftung.de/spotlight 